\title{
Horizontal-resource models of happiness
}

\author{
Elena Gennadievna Ksenofontova $^{{ }^{*}}$ and Elena Albertovna Sverdlikova ${ }^{1}$ \\ ${ }^{1}$ Lomonosov Moscow State University, Economic Sociology and Management Subdepartment, \\ Faculty of Sociology, Moscow, Russia
}

\begin{abstract}
Happiness" is not even considered by many as a scientific term. Meanwhile, some practitioners are concerned with improving the quality of life and the objective reasons for people's subjective satisfaction while others note the prevalence of problems related to "unhappiness". Thus, in the best case, people turn to clergy, significant others, or psychotherapists to change either themselves or their lives for the better. However, theoretical interpretations of the phenomenon of happiness in many sciences that are based on the models of balance, the correspondence between the desired and the available, etc., use a fragmented and practically unstructured terminological apparatus. The goal of the study is to identify the conceptual models in all the diversity of interpretations and studies of happiness that allow uniting groups of researchers from different fields of knowledge, as well as to present the views of the authors of artworks on the mechanisms of experience and empathy with the processes of gaining and losing happiness. Methods: Comparative analysis of views on the phenomenon of happiness and the related states presented in works of art, spiritual and cultural life, and studies of the social and human sciences. The analyzed material allowed us to show the presence of a large number of models of interpretation of the state of happiness often associated with the assessment of resources available to the individual (horizontal-resource models of happiness). This distinguishes them from the vertical-level models that contrast the highest levels of happiness of special quality with the manifestation of different, lower-order states also referred to as happiness. It is important to note that in horizontal-resource interpretations, many models do not treat happiness simply as a significant share "of the total pie". Resource-based approaches assess the available or absent potential (of varying nature), as well as the absence or presence of the possibility of approaching a subjectively meaningful state.
\end{abstract}

Keywords: Personality, Motivation, Value systems, Self-esteem.

\begin{abstract}
Since numerous conceptions and even more terms that touch upon the issue of "happiness" in one way or another have accumulated over the lifetime of the multilingual human race, they are all somehow structured in the semantic space of specific languages, social groups, and times. Some terms include others or are opposed to them, the "obsolete" and neglected ones are replaced with newer terms that, however, are often mere calques of foreign words. The shades of meaning and contexts of using the same word change to the opposite. For
\end{abstract}

\footnotetext{
*Corresponding author: eksen@mail.ru
} 
some, personal happiness as a value is natural and unconditional while for others, the pursuit of individual happiness is not justified when others are suffering nearby or even somewhere very far away.

Even the traditionally obvious explanation of the Russian word "happiness" ["schaste"] based on the root "part" ["chast"] has ambiguous interpretations. Shades of meaning and contexts of using the same word change to the opposite.

On the one hand, it emphasizes the individual as "part of the community", most often the family, rejoicing in being part of a single whole and providing their unique contribution to that whole.

On the other hand, some people see the Sanskrit roots of the word "happiness" and interpret it as slchast [part], good one given to you destiny. That is, not a person is part of something greater but a better part is given to them from above compared to others. However, there are also other interpretations: a good fortune is a chance to do something useful. And this happiness - an opportunity to fulfill one's mission, a fate: no matter small or large but an important social role.

On the third hand, some emphasize the joy of receiving a benefit: left with-a piece [schastiu] of the common pie in the allocation of scarce resources. In this logic, even the English word value translates solely as price-benefit-value and not as significance-valuepricelessness.

Such incompleteness or partiality is not always due to the fact that someone has "stolen" all possible happiness or wants to "snatch a piece of happiness" from another. There was a time when humanity, reveling in scientific and technological progress, considered it its duty not to wait but to "take favors from nature" making itself as happy as possible at its expense. Nature seemed resource-boundless and the right to war and fight for resources was justified by the "laws of the world order" and the rights of the strong: "If we can take/take away, why should we not?!". Nowadays, vegetarians, the "green" movement, and "sustainable development" programs are predicting many unhappy generations and calling on contemporaries to reconsider their understanding of happiness for those living now. These activists feel happy if at least someone listens to them and begins to take real action to bring happiness back to someone other than them: the Amur tigers, all the wild and not only wild nature, and, which is even more difficult, the world's oceans and the planet's climate.

A similar view is found in folk tales of unselfish kindness and receiving support in moments of misfortune "when one does not expect it". Most often this support comes from the outside. Sometimes, however, it even appears as new forces from within oneself (inner resources). It turns out that spending a "positive resource" only multiplies it. Internal "happiness not for show" or the seemingly irrational belief either in the possibility of happiness (good) or in the rightfulness of doing good deeds for others give strength to act, to warm up and support others.

Both world literature and cinematography have always drawn attention to the nonabsoluteness and ambiguity of the feeling of happiness and its kindred states. The relativity of assessing the state of happiness is shown through a variety of techniques of background or contrast capable of leading the viewer-reader even to a state of catharsis. Happiness as an intense positive emotion is felt the stronger the brighter the contrast. Sometimes, art shows examples of the cost of the obtained state. An example understandable even by its title is the 1958 Soviet film "Difficult Happiness". More often, however, art creates a "pinching feeling" of the formerly possible but never realized happiness. It becomes especially acute with the juxtaposition of the title of the work and the fate of the creator or with the reminder of the opportunities that were never realized. "Viktor was looking out the window at the barge sailing past, $<\ldots>$ thinking that everything was still to come and that everything would happen to him, that the most paramount and important thing that should happen in everyone's life 
will happen, and he was convinced of this, although every time he was losing more than he was finding," - the film "A Long Happy Life", 1966 [1].

Attempts to represent happiness through opposite states are quite typical, particularly since negative emotions are stronger than positive ones and are in some ways even more diverse. Moreover, as the Russian proverb says, "what we have, we do not appreciate, and when we lose it, we cry". The first words of the novel "Anna Karenina" are characteristic: "All happy families are alike; every unhappy family is unhappy in its own way" [2]. And it is characteristic that the apparent absence of unhappiness and the availability of financial means are no guarantee of happiness. Meanwhile, modern Russians [3] who consider themselves happy after a year of living in the pandemic name their own and their relatives' health in the first place, having a family and well-being in it in the second place, and having children in the third place among the reasons for feeling happy. The unhappy complain about the lack of resources and opportunities to obtain them which is yet another reminder to the state authorities, as well as the authorities of most other countries, about the critical importance of ensuring the viability of various sectors of the economy.

Interestingly, as early as 330 B.C. Aristotle spoke of happiness as the highest goal of the state [4] despite the fact that he considered each person to be the source of the feeling of happiness. Before him, Xenophonte who is considered the founder of economics and author of the first work called Oeconomicus (or Domostroy) wrote in about 361 B.C. about the difference between a good and a bad owner of an accessible for him part of the world - their home or the entire "oecumene". The one who multiplies the available resources through labor and correct organization of their own and others' work is the one who feels good. Xenophon is credited with the following quote: "Happiness is all the more satisfying the more you labor before you attain it. For labor is the spice of happiness". In "Oeconomicus", however, Xenophon does not seem to have used the word "happiness". Nor does the Russian Domostroy written many centuries later by Silvestr that emphasizes the great importance of spiritual benefits that are not reduced to labor solely for the sake of increasing material wealth $[5,6]$.

In the books collected by V. I. Dahl by the $1850-1860$ years of proverbs there are examples of statements about luck and happiness [7]. The National Corpus of the Russian language also indicates the active use of the word "happiness" since at least 1800 (from the beginning of the historical base of the study) and an increase in its use by the middle of the 19th century. At that time, the abolition of serfdom was being prepared in Russia and the war "with slavery" was brewing in the United States. With slavery that has reminded us in the 21 st century that the normal, i.e. not deprived of the possibility of happiness, "black lives" should not be of lesser but, as compensation, perhaps even of greater importance.

Researchers of social relations pay attention to the suddenly manifesting charisma, energy, and even passionarity of peoples and leaders. In all these cases, moving toward the desired "ignites" others with a sense of happiness not from the result but from the process of moving toward it [8]. However, Francis Fukuyama speaks not only of peaks but also of the abysses of thymos, the positive energy of self-respect and pride: this value of liberal democracy degenerates into hubris and entails conflicts for individuals suffering from excessive conceit [9]. Happiness evaporates and only the struggle is left. It is not without reason that people sometimes joke: "It is clear that you have to fight for happiness. But it is not clear - with whom?!" It becomes clear if we oppose ourselves to the modern authorities. After all, it is the authorities who are obliged to provide citizens with "the quality of life" and "objective well-being". Sociologists can then ask citizens how they experience this wellbeing subjectively [10-16]. The authorities have no other object of analysis reflecting human happiness. Unless, of course, we consider the Buddhist country of Bhutan with its ministry and commission on universal national happiness or the anti-utopia of the Brave New World 
in which both pills of happiness and programs of the feeling of happiness are developed for each category of people [17].

Thus, happiness as an object of external care is closest to the subjective well-being of the population. However, care for happiness depends on a variety of cognitive-psychological characteristics and life situations of specific people assessing the opportunities available to them that affect the attainability or the principal unattainability (remoteness) of a certain state of happiness meaningful for them. The variety of such views on "happiness" is presented in Table 1.

Table 1. Examples of the horizontal-resource "happiness models"

\begin{tabular}{|c|c|}
\hline $\begin{array}{l}\text { National happiness indices } \\
\text { Common - individual }\end{array}$ & $\begin{array}{l}\text { - GDP as a resource allowing to acquire the necessary } \\
\text { - The number of social programs as a means of providing } \\
\text { additional resources for those in need } \\
\text { - The ability to influence decisions as a resource of power and } \\
\text { control in vital areas, etc. }\end{array}$ \\
\hline $\begin{array}{l}\text { Subjective assessment of } \\
\text { satisfaction } \\
\text { Ideal - real }\end{array}$ & $\begin{array}{l}\text { - The proportion of fulfilled desires realized in relation to the } \\
\text { volume of opportunities } \\
\text { - Easterlin paradox as a demonstration of different perceptions } \\
\text { of the volume of opportunities in different countries }\end{array}$ \\
\hline $\begin{array}{l}\text { Black lives matter }>\text { white } \\
\text { lives matter } \\
\text { Past - present }\end{array}$ & $\begin{array}{l}\text { - The requirement of redistribution of sustenance and power } \\
\text { resources as a restoration of justice and compensation for } \\
\text { historical injustice }\end{array}$ \\
\hline $\begin{array}{l}\text { Sustainable development } \\
\text { concept } \\
\text { Present - future }\end{array}$ & $\begin{array}{l}\text { - Today's wellbeing and its growth should not be at the expense } \\
\text { of tomorrow's wellbeing } \\
\text { - Particular cases: ecological resources of the planet; the needs } \\
\text { of the next generations, etc. }\end{array}$ \\
\hline $\begin{array}{l}\text { Work-Life Balance } \\
\text { Normal - excessive } \\
\end{array}$ & $\begin{array}{c}\text { - Work can take excessive amounts of a person's time and } \\
\text { energy resources (when these spheres are imbalanced) }\end{array}$ \\
\hline $\begin{array}{l}\text { Cognitive estimates of } \\
\text { probability } \\
\text { Real - unreal }\end{array}$ & $\begin{array}{l}\text { - The phenomenon of "half a glass" and optimism/pessimism } \\
\text { as a belief in the possibility/impossibility of obtaining the } \\
\text { desired } \\
\text { - Internal/external locus of control of consequences as a } \\
\text { proportion of possible influence on the results of one's } \\
\text { actions. The degree of happiness is determined by forces } \\
\text { independent of the individual (fate, luck, etc.) } \\
\text { - Feliciticitous - dysthymic images of the world }\end{array}$ \\
\hline $\begin{array}{l}\text { Relativist models of } \\
\text { happiness } \\
\text { Unhappiness }\end{array}$ & $\begin{array}{l}\text { - The model of minimization of hardship, suffering, and } \\
\text { adversity } \\
\text { - The acuteness of the sense of happiness in contrast to } \\
\text { unhappiness } \\
\text { - The immediacy or impossibility of happiness here-and-now } \\
\text { - Happiness as warmth that is transferable and impossible to } \\
\text { lose }\end{array}$ \\
\hline
\end{tabular}

In the future, the material discussed here may prove useful to researchers from various fields. After the fall of the Tower of Babel that deprived us of the happiness of understanding everyone speaking "not our" languages and other professional jargons, humanity is facing an even greater blow - the loss of the opportunity to live in the common semantic field with one's neighbors and relatives from different generations: sitting on the same sofa, people can stay in absolutely non-overlapping social platforms and networks, lifeworlds and conceptospheres. This is unlikely to make anyone happy... 


\section{References}

1. G. F. Shpalikov, Izbrannoe: Stsenarii. Stikhi i pesni. Razroznennye zametki [Selected: Scripts. Poems and songs. Miscellaneous Notes] (Iskusstvo, Moscow, 1979)

2. L.N. Tolstoy, Anna Karenina. Accessed on: December 20, 2020. [Online]. Available: https://liteka.ru/english/library/2129-anna-karenina\#appMainContent

3. The Happiness Index - 2021. Analytical review by VTsIOM (2021). Accessed on: March 29, 2021. [Online]. Available: https://wciom.ru/analyticalreviews/analiticheskii-obzor/indeks-schastja-2021

4. S. N. Kocherov, Schole. Ancient Philosophy and the Classical Tradition, 14(2), 470 482 (2020). https://doi.org/10.25205/1995-4328-2020-14-2-470-482

5. A. Iu. Tikhonovich, "Oikonomika" Ksenofonta i russkii "Domostroi” $16 \mathrm{v}$ : skhodstvo i otlichiia [Xenophon's "Oeconomicus" and the Russian "Domostroy" of the 16th century: commonalities and differences.], in N.N. Nizhneva (Ed.), Idei. Poiski. Resheniya [Ideas. Search. Solutions] (Belarusian State University, Minsk, 2017). Accessed on: March 29, 2021. [Online]. Available: http://elib.bsu.by/handle/123456789/164719

6. O. A. Platonov (Ed.), Domostroi. Poucheniia i nastavleniia vsiakomu khristianinu [Domostroy. Teachings and Exhortations for Every Christian] (Institut russkoi tsivilizatsii, Rodnaia strana, Moscow, 2014). Accessed on: March 29, 2021. [Online]. Available:https://rusinst.su/docs/books/Domostroi.pdf

7. V. I. Dal, Poslovitsy russkogo naroda [Proverbs of the Russian people]. Accessed on: March 29, 2021. [Online]. Available: https://ru.wikisource.org/wiki/пословицы_русского_народа_(Даль)

8. E. G. Ksenofontova, Izvestiya of Saratov University. Sociology. Politology, 16(2), 142-153 (2016). https://doi.org/10.18500/1818-9601-2016-16-2-142-147

9. F. Fukuyama, Borba za priznanie. Vershiny i bezdny timosa [The struggle for recognition. The peaks and abysses of thymos], in F. Fukuyama, Konets istorii i poslednii chelovek [The end of history and the last man] (AST Publishing house, Politgrafizdat, Moscow, 2010). Accessed on: March 29, 2021. [Online]. Available: https://gtmarket.ru/library/basis/6341/6358

10. Y.P. Averin, V.A. Sushko, Espacios, 40(24), 7-14 (2019)

11. Y.P. Averin, V.A. Sushko, Postmodern Openings, 11(2, Supl 1), 1-15 (2020)

12. S.A Barkov, O.V. Gavrilenko, A.V.Markeeva, E.A. Sverdlikova, Problems of Economic Transition, 61(1-3), 248-265 (2019). https://doi.org/10.1080/10611991.2019.1691891

13. R. Veenhoven, The sociology of happiness: topic in social indicators research, in Proceedings of common sessions of the isa Forum, 1-13 (2016). Accessed on: March 29, 2021. [Online]. Available: https://personal.eur.nl/veenhoven/Pub2010s/SociologyOfHappiness2_ISAbook.pdf

14. P. Conzo, A. Aassve, G. Fuochi, L. Mencarini, Journal of Economic Psychology, 62, 268-283 (2017). https://dx.doi.org/ 10.1016/j.joep.2017.08.001

15. B. Q. Ford, J. O. Dmitrieva, D. Heller, Yu. Chentsova-Dutton, I. Grossmann, M. Tamir, Yu. Uchida, B. Koopmann-Holm, V. A. Floerke, M. Uhrig, T. Bokhan, I. B. Mauss, Journal of Experimental Psychology: General, 144(6), 1053-1062 (2015). https://dx.doi.org/10.1037/xge0000108 
16. E. V. Galazhinskii, T. G. Bokhan, A. L. Ulianich, O. V. Terekhina, M. V. Shabalovskaia, Science for Education Today, 6, 19-38 (2019). https://dx.doi.org/10.15293/2658-6762.1906.02

17. A. Huxley, O divnyi novyi mir [Brave New World], 131-271 (Knizhnaia palata, Moscow, 1989) 